\title{
Angiotensin II Causes Weight Loss and Decreases Circulating Insulin-like Growth Factor I in Rats through a Pressor-independent Mechanism
}

\author{
Marijke Brink, Jason Wellen, and Patrick Delafontaine \\ Emory University, Division of Cardiology, Atlanta, Georgia 30322
}

\begin{abstract}
The renin-angiotensin system regulates normal cardiovascular homeostasis and is activated in certain forms of hypertension and in heart failure. Angiotensin II has multiple physiological effects and we have shown recently that its growth-promoting effects on vascular smooth muscle require autocrine activation of the IGF I receptor. To study the effect of angiotensin II on circulating IGF I, we infused rats with $500 \mathrm{ng} / \mathrm{kg} / \mathrm{min}$ angiotensin II for up to $14 \mathrm{~d}$. Angiotensin II markedly reduced plasma IGF I levels (56 and $41 \%$ decrease at 1 and $2 \mathrm{wk}$, respectively) and IGF binding protein-3 levels, and increased IGF binding protein-2 levels, a pattern suggestive of dietary restriction. Compared with sham, angiotensin II-infused hypertensive rats lost $18-26 \%$ of body weight by $1 \mathrm{wk}$, and pair-feeding experiments indicated that $74 \%$ of this loss was attributable to a reduction in food intake. The vasodilator hydralazine and the $\mathrm{AT}_{1}$ receptor antagonist losartan had comparable effects to reverse angiotensin II-induced hypertension, but only losartan blocked the changes in body weight and in circulating IGF I and its binding proteins produced by angiotensin II. Moreover, in Dahl rats that were hypertensive in response to a high-salt diet, none of these changes occurred. Thus, angiotensin II produces weight loss through a pressor-independent mechanism that includes a marked anorexigenic effect and an additional (likely metabolic) effect. These findings have profound implications for understanding the pathophysiology of conditions, such as congestive heart failure, in which the renin-angiotensin system is activated. (J. Clin. Invest. 1996. 97:2509-2516.) Key words: congestive heart failure $\cdot$ hypertension $\bullet$ IGF binding proteins $\cdot$ metabolism $\bullet$ receptors, growth factor
\end{abstract}

\section{Introduction}

Angiotensin II (ang II), ${ }^{1}$ the main effector molecule of the renin-angiotensin system (RAS), has multiple physiological effects. It maintains sodium and water balance through a variety

Address correspondence to Patrick Delafontaine, Emory University, Division of Cardiology, 1639 Pierce Dr., 319 WMB, Atlanta, GA 30322. Phone: 404-727-8119; FAX: 404-727-3330.

Received for publication 21 December 1995 and accepted in revised form 12 March 1996.

1. Abbreviations used in this paper: ACE, angiotensin-converting enzyme; ang II, angiotensin II; IGFBP(s), IGF binding protein(s); RAS, renin-angiotensin system; TBS, Tris-buffered saline.

J. Clin. Invest.

(C) The American Society for Clinical Investigation, Inc.

0021-9738/96/06/2509/08 \$2.00

Volume 97, Number 11, June 1996, 2509-2516 of effects on the central nervous system, the adrenal gland, the vasculature, and the kidney. These effects include stimulation of aldosterone secretion (1), enhancement of sodium and water reabsorption $(2,3)$, and stimulation of thirst, sodium appetite, and vasopressin and ACTH release (for reviews see references 4-6). ang II is also a vascular and cardiac growth factor (7-12). A pathophysiologic role for increased circulating and/ or tissue ang II has been suggested by experimental and clinical data. Thus, beneficial effects of RAS antagonism (using angiotensin-converting enzyme [ACE] inhibitors or ang II receptor antagonists) have been demonstrated in animal models of cardiac hypertrophy and of mechanical arterial injury (for reviews see references 13 and 14). The major mortality benefit of ACE inhibitors in chronic heart failure has further substantiated the concept that chronic activation of the RAS (a hallmark of chronic heart failure) has detrimental consequences (15-21). Thus, in patients with high-renin hypertension, there is an increased risk of myocardial infarction (22-24), although the mechanisms for this remain unexplained.

Another vital hormonal and autocrine/paracrine system is the insulin-like growth factor I (IGF I) system. IGF I circulates at high levels in plasma and is a major regulator of developmental growth (for review see reference 25) and protein anabolism (26). IGF I is also synthesized in most tissues where it has important effects on cell growth, differentiation, and survival (25). We have shown recently that in cultured rat aortic smooth muscle cells the growth promoting effects of ang II require an active IGF I autocrine system (27). Indeed, transcriptional activation of IGF I (27) and IGF I receptor (28-30) expression are key components of vascular growth responses to ang II. However, in rat interrenal abdominal aortic coarctation, a condition in which vascular IGF I expression is increased, there is a trend toward lower circulating IGF I levels (31). This has suggested that activation of the RAS could lead to tissue-specific effects on IGF I expression, and specifically, a potential reduction in circulating IGF I. To study potential effects of ang II on circulating IGF I and its binding proteins (IGFBPs), we infused rats with ang II. Our results demonstrate a novel and previously unsuspected effect of ang II to cause marked weight loss, concordant with a marked depression in circulating IGF I. This effect is mediated by the $\mathrm{AT}_{1}$ receptor, but is independent of pressor effects. ang II-induced weight loss is secondary to both a reduction in food intake and another, probably metabolic, effect. These results could be particularly relevant to understanding the pathophysiology of hyperreninemic states in humans, and specifically of conditions characterized by chronic activation of the RAS.

\section{Methods}

Animals. We performed studies using male Sprague-Dawley rats of 290-360 grams obtained from Harlan Laboratories (Prattville, AL). Animals were housed in individual cages under standard conditions. Three experiments were performed, each consisting of different animal groups ( $n \geq 4$ per group per time point), all involving the implan- 
tation of osmotic minipumps (Alzet model 2001 or 2002; ALZA Corp., Palo Alto, CA). Rats were anesthetized with $80 \mathrm{mg} / \mathrm{kg}$ ketamine and $12 \mathrm{mg} / \mathrm{kg}$ xylazine, and the pumps were placed subcutaneously in the subscapular region. ang II was dissolved in saline acidified with $0.01 \mathrm{M}$ acetic acid to maintain its stability and was infused at a rate of $500 \mathrm{ng} / \mathrm{kg} / \mathrm{min}$. Sham animals were infused with vehicle.

The first experiment aimed to assess the effects of ang II infusion on the IGF I system over time and consisted of four groups of rats: one group was infused for $1 \mathrm{wk}$ and one group for $2 \mathrm{wk}(n=4$ per group). The two other groups ( $n=4$ per group) were sham-infused correspondingly. In the second experiment, six groups of rats were studied ( $n=4-6$ per group): sham- or ang II-infused rats that received drinking water with or without hydralazine $(10 \mathrm{mg} / \mathrm{kg} / \mathrm{d})$ or losartan $(25 \mathrm{mg} / \mathrm{kg} / \mathrm{d})$. Losartan was kindly provided by Dr. R. Smith (DuPont Merck, Wilmington, DE). All antihypertensive treatments were started $2 \mathrm{~d}$ before implantation of the minipumps, and ang II was administered for $1 \mathrm{wk}$. For the third experiment (pair-feeding experiment) three groups of rats were used ( $n=4$ per group). The food intake of a group of ang II-infused animals was weighed daily to the nearest gram. A second group of animals was infused with vehicle only and was administered a restricted amount of food identical to that eaten by the ang II-infused rats. A third group of animals received vehicle-containing pumps and normal chow ad libitum.

Systolic blood pressures were measured in restrained awake rats before the start of the antihypertensive treatment, before implantation of the minipumps, and at 3, 7, and $14 \mathrm{~d}$ after surgery using the tail cuff method. The mean blood pressure was calculated from three or more tracings. The rats were weighed to the nearest gram. 1 or $2 \mathrm{wk}$ after implantation of the pumps, animals were killed under anesthesia, their blood was taken, mixed with EDTA in prechilled glass tubes, and transferred to ice immediately. Plasma was obtained after centrifugation for $10 \mathrm{~min}$ at $4^{\circ} \mathrm{C}$ at $2,000 \mathrm{rpm}$ and stored at $-80^{\circ} \mathrm{C}$ until analysis by radioimmunoassay, Western ligand blotting, or immunoblotting.

6-wk-old Dahl salt-sensitive and salt-resistant rats (inbred Rapp strain) were purchased from Harlan Sprague Dawley, Inc. (Indianapolis, IN) and were kept on a low-salt diet $(0.3 \% \mathrm{NaCl})$ or a high-salt diet $(8 \% \mathrm{NaCl})$ for $2 \mathrm{wk}$ (Harlan Teklad, Madison, WI). Their systolic blood pressures were taken and plasma was prepared as described above for the Sprague-Dawley rats.

IGF I radioimmunoassay. Plasma samples were treated with acidethanol to separate IGFBPs from IGF I essentially as described (32). The recovery of IGF I using this method was $70 \pm 2 \%$. The extracted plasma samples were assayed for IGF I immunoreactivity as described previously (33). A polyclonal anti-IGF I rabbit antiserum kindly provided by Dr. L. Underwood and Dr. J.J. Van Wyk through the National Hormone and Pituitary Program of the National Institute of Diabetes and Digestive and Kidney Diseases was used. A double antibody technique was used to precipitate bound counts using goat anti-rabbit antiserum and normal rabbit serum as a carrier. Standard curves were generated using human recombinant IGF I kindly provided by Dr. H.P. Guler (Ciba-Geigy Corp., Summit, NJ). In a preliminary experiment we established that plasma or serum gave identical results.

Western ligand blotting. Plasma samples from all rats were submitted to Western ligand blotting essentially as described previously (31). In brief, plasma was acidified with $2 \mathrm{~N}$ acetic acid for $30 \mathrm{~min}$ at room temperature, neutralized by addition of $2 \mathrm{~N} \mathrm{NaOH}$, mixed with SDS sample buffer, boiled, and electrophoresed on a 12\% SDS-polyacrylamide minigel and transferred to nitrocellulose. The blots were dried and sequentially blocked with $0.3 \%$ Nonidet P-40 (30 min), $1 \%$ BSA $(1 \mathrm{~h})$, and $0.1 \%$ Tween $20(10 \mathrm{~min})$ in $10 \mathrm{mM}$ Tris-buffered saline (TBS, $\mathrm{pH}$ 7.4). The blots were then incubated overnight with $4 \times 10^{5}$ $\mathrm{cpm} / \mathrm{ml}$ of ${ }^{125} \mathrm{I}$-IGF $\mathrm{I}$ in the presence of $0.5 \%$ BSA and $0.05 \%$ Tween 20 , washed with two changes of $0.1 \%$ Tween 20 in TBS, and two changes of TBS, and exposed to film for 1-3 d. Prestained molecular weight markers (Bio Rad Laboratories, Hercules, CA) were used for sizing.
Western immunoblotting. Plasma samples were boiled in SDS sample buffer, run on a $12 \%$ SDS-polyacrylamide minigel, and transferred to nitrocellulose. The blot was incubated overnight with $1 \%$ milk powder in PBS, for at least 30 min with $1 \%$ BSA, and for $1 \mathrm{~h}$ with a rabbit anti-IGFBP-2 or anti-IGFBP-3 antibody (kindly provided by Dr. S. Shimasaki, Whittier Institute for Diabetes and Endocrinology, Scripps Memorial Hospital, La Jolla, CA); or anti-IGFBP-1 antibody (kindly provided by Dr. R.C. Baxter, Kolling Institute of Medical Research, St. Leonards, New South Wales, Australia) in PBS containing $1 \%$ BSA and $0.1 \%$ Tween 20 . After several washes the blots were incubated with an alkaline phosphatase-conjugated goat anti-rabbit secondary antibody, washed again, and colored with $p$-nitroblue tetrazolium chloride and 5-bromo-4-chloro-3-indolyl phosphate (NBT/BCIP, Bio Rad Laboratories).

Northern analysis. Total RNA was prepared from frozen liver using the RNeasy kit (QIAGEN Inc., Chatsworth, CA) according to the manufacturer's instructions and Northern analysis was performed as described previously (34). Briefly, 20- $\mu$ g samples of total RNA were size-fractionated by agarose-formaldehyde gel electrophoresis and transferred to nylon membranes. RNA loading and transfer efficiencies were verified by methylene blue staining of membranes. Membranes were prehybridized for $2 \mathrm{~h}$ and then hybridized overnight in $5 \times$ SSC, $5 \times$ Denhardt's solution, $1 \%$ SDS, $100 \mathrm{mg} / \mathrm{ml}$ denatured salmon sperm DNA, and $5 \times 10^{5} \mathrm{cpm} / \mathrm{ml}{ }^{32} \mathrm{P}$-labeled IGF I exon $3 \mathrm{cDNA}$ at $65^{\circ} \mathrm{C}$. The IGF I cDNA was kindly provided by Dr. P. Rotwein (Washington University School of Medicine, St. Louis, MO). After hybridization the filters were washed with $2 \times$ SSC and $0.2 \%$ SDS $2 \times$ $30 \mathrm{~min}$ at room temperature and $2 \times 30 \mathrm{~min}$ at $65^{\circ} \mathrm{C}$, then with $0.1 \times$ SSC for $15 \mathrm{~min}$ before autoradiography. The molecular sizes of the detected RNA species were determined from the migration pattern of a 0.24-9.5-kb RNA ladder (GIBCO BRL, Gaithersburg, MD). As an additional control for loading and transfer of RNA samples, filters were cohybridized with a GAPDH cDNA probe (35).

Hematocrit levels. These were measured in ang II-infused and pair-fed sham-infused rats, using a standard method (36).

Statistical analysis. All data represent means of at least four rats in each group and values are expressed as mean \pm SEM. Time course analysis was performed using ANOVA, and comparisons between groups were performed using a protected Tukey's $t$ test. Differences in IGF I levels between groups were analyzed using Student's $t$ test.

\section{Results}

Effect of ang II infusion on blood pressure. To study the effect of ang II on the circulating IGF I system in vivo, we infused rats with $500 \mathrm{ng} / \mathrm{kg} / \mathrm{min}$ ang II through osmotic minipumps up until 2 wk. Compared with sham, systolic blood pressures increased by $8 \%$ at $3 \mathrm{~d}(P=0.14), 33 \%$ at $7 \mathrm{~d}(P<0.01)$, and $42 \%$ at $14 \mathrm{~d}(P<0.01)$. Sham-operated animals that received minipumps containing vehicle only did not significantly change their pressure during these 2 wk (Fig. 1).

Effect of ang II infusion on IGF I and IGFBP levels. In the ang II-infused hypertensive rats, plasma IGF I levels were reduced by $56 \%$ at 1 wk of treatment $(P<0.01)$ and by $41 \%$ at 2 wk $(P<0.02)$, compared with sham (Fig. 2$)$. Northern analysis indicated that hepatic IGF I mRNA levels were markedly reduced in ang II-infused animals (not shown).

As the availability and activity of IGF I in tissue is highly regulated by interactions with IGFBPs, we determined levels of IGFBPs in plasma of the ang II-treated and sham rats at 7 and $14 \mathrm{~d}$ by Western ligand blotting and immunoblotting. For each plasma sample five labeled bands were observed on autoradiographs of Western ligand blots (Fig. $3 A$ ). Three bands clustered around an apparent molecular mass of $38-45 \mathrm{kD}$, representing IGFBP-3. The band detected at $\sim 30-31 \mathrm{kD}$ may 


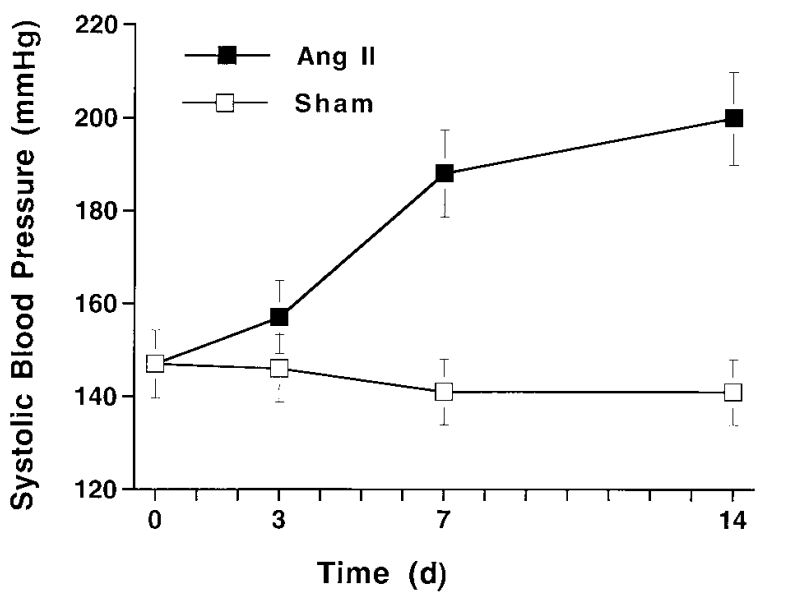

Figure 1. Effect of ang II on systolic blood pressure. Systolic blood pressures were measured in sham-infused and ang II-infused rats at indicated times, as described in Methods. Shown is the mean $\pm \mathrm{SE}$ of measurements from four to eight rats per time point per condition.

represent either IGFBP-1 and/or IGFBP-2, and the fifth band at $24 \mathrm{kD}$ corresponds to IGFBP-4. In ang II-treated rats IGFBP-3 was strongly reduced, compared with sham animals (Fig. $3 A$ ). Densitometric analysis indicated a $64 \pm 6 \%$ and a $62 \pm 12 \%$ reduction at 7 and $14 \mathrm{~d}$, respectively. There was no consistent change in the $30-31-\mathrm{kD}$ band and in the $24-\mathrm{kD}$ band as detected by Western ligand analysis. As observed changes in IGFBPs may reflect changes in the actual amount of protein or a shift in affinity of the binding protein for the radiolabeled IGF I, we performed Western immunoblotting. Immunoblotting with an anti-IGFBP-3 antibody showed that IGFBP-3 was markedly downregulated at the protein level (Fig. $3 B$ ). Analysis with an anti-IGFBP-2 antibody showed a strong upregulation of IGFBP-2 in all ang II-treated animals (Fig. $3 \mathrm{~B}$ ). Probing with an anti-IGFBP-1 antibody demonstrated no detectable IGFBP-1 in sham animals and a weak signal in ang II-treated animals (not shown). Detection of IGFBP-4 by immunoblotting revealed that the amount of this protein was unchanged in response to ang II infusion in all rats (Fig. $3 B$ ).

Effect of antihypertensive treatment on ang II-induced changes in blood pressure, IGF I, and IGFBPs. Pharmacological treatment of rats with either losartan or hydralazine was

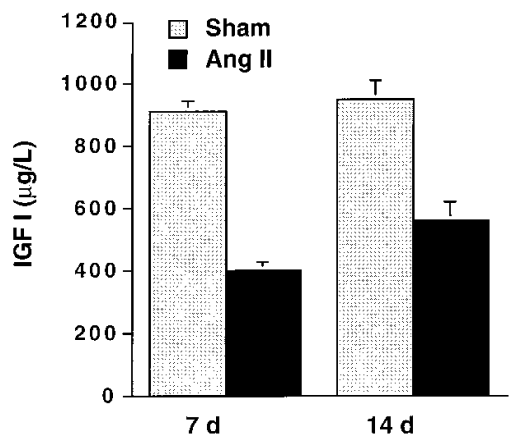

Figure 2. IGF I levels in sham- and ang II-infused animals. Total circulating IGF I levels in plasma from sham- and ang II-infused animals were determined by radioimmunoassay as described in Methods. Shown is the mean \pm SE of duplicate determinations from four animals per condition per time point.

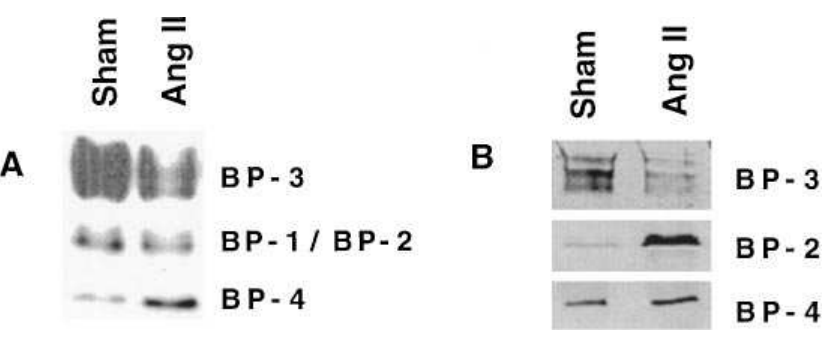

Figure 3. Effect of ang II on IGFBPs. Plasma from sham-infused and ang II-infused rats at $2 \mathrm{wk}$ was subjected to Western ligand blotting with ${ }^{125}$ I-IGF I $(A)$ and Western immunoblotting $(B)$ as described in Methods. Shown is a representative experiment, repeated on three additional groups of rats.

started $2 \mathrm{~d}$ before sham or ang II infusion. Both losartan and hydralazine caused a similar reduction in blood pressure in the sham-infused animals at $6 \mathrm{~d}(P=0.01$ and $P=0.025$, respectively, compared with control), although the decrease with hydralazine was more rapid (Fig. 4, Sham). In rats infused with ang II and receiving either losartan or hydralazine, blood pressures at $7 \mathrm{~d}$ reached levels that were not significantly different from normotensive sham-infused control animals $(P=0.6$ and $P=0.8$, respectively, Fig. 4, Ang II).

Measurements of IGF I levels in these animals are shown in Fig. 5. ang II reduced IGF I levels by $57 \%$ at $7 \mathrm{~d}$, compared with sham, and this ang II-induced decrease in IGF I was completely blocked by administration of losartan. The small difference in IGF I levels observed between losartan-treated shamand ang II-infused animals was not statistically significant $(P=0.15)$. Losartan by itself, despite its blood pressure-lowering effects, did not significantly affect IGF I levels as compared with control sham animals. Despite its pressure-normalizing effects, hydralazine did not prevent the decrease in IGF I levels in ang II-infused rats. Thus, rats treated with ang II and receiving hydralazine had plasma IGF I levels that were significantly lower $(P<0.01)$ than in sham-operated animals receiving hydralazine, and similar to the levels found in ang IItreated control animals $(P=0.25)$. Hydralazine alone produced a small decrease in IGF I levels, compared with shaminfused control animals $(P<0.05)$. Similar to its effects on IGF I, losartan completely prevented the ang II-induced decrease in IGFBP-3 and increase in IGFBP-2, whereas hydralazine did not affect either of these changes (Fig. 6).

Body weight and pair-feeding experiments. The changes observed in circulating IGF I and IGFBPs in response to ang II infusion are very similar to changes described previously with dietary restriction. As shown in Fig. $7 A$, ang II-infused animals gradually lost weight up to $1 \mathrm{wk}$ (18\% reduction compared with sham, $P<0.0001)$ and during the second week they kept this weight, which was significantly lower $(P<0.005)$ than that measured for the sham-infused animals that continued to gain weight slowly. The body weights of animals used for the second experiment (i.e., receiving antihypertensives) are shown in Fig. 7 B. In this experiment, ang II induced a $26 \%$ loss in body weight at $1 \mathrm{wk}$, compared with sham controls, and losartan completely inhibited this loss in weight. Although administration of the vasodilator hydralazine to ang II-infused animals resulted in a normalization of blood pressure (Fig. 4), these animals still showed a dramatic drop in body weight. Thus, hydralazine-treated ang II-infused animals had a similar 
Sham

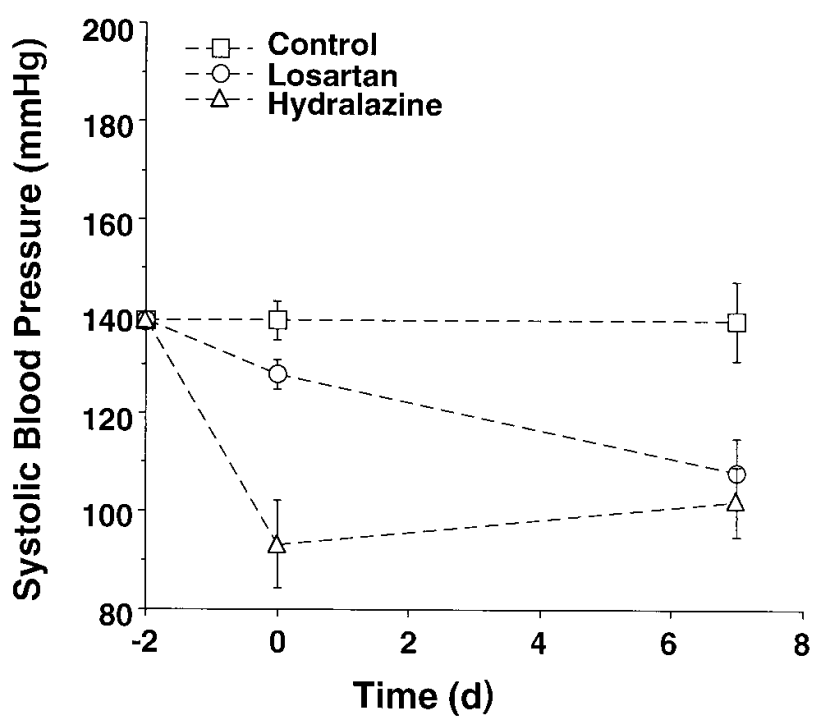

Ang II

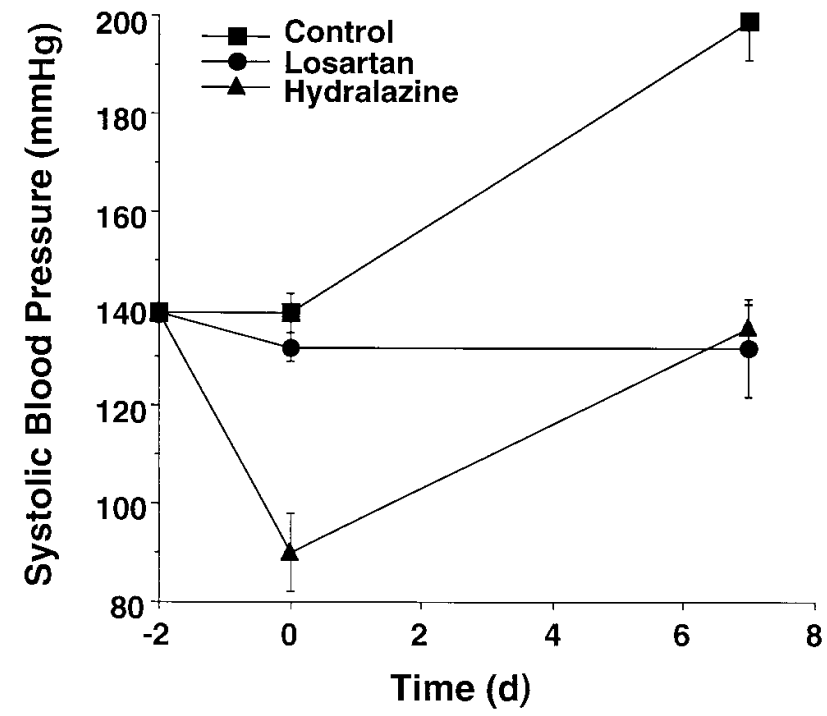

Figure 4. Effects of hydralazine and losartan on blood pressure. Systolic blood pressure was measured at indicated times in sham-infused and ang II-infused rats receiving no antihypertensive therapy (Control) or receiving $25 \mathrm{mg} / \mathrm{kg} / \mathrm{d}$ losartan or $10 \mathrm{mg} / \mathrm{kg} / \mathrm{d}$ hydralazine. Shown is the mean $\pm \mathrm{SE}$ of measurements from four to six animals per condition per time point.

body weight to ang II-infused control animals. Hydralazine alone caused a small, not statistically significant reduction in weight at $1 \mathrm{wk}$, compared with sham controls.

To determine whether ang II-induced reductions in body weight and IGF I levels were secondary to reduced food intake, we performed pair-feeding experiments. The mean daily food intake of sham-infused animals was $22 \pm 0.7$ grams, whereas ang II-infused animals ate only $5 \pm 0.6$ grams of rat chow daily. Another group of sham-infused animals was pairfed, i.e., their food intake was limited to the exact amount eaten by the ang II-infused animals. The growth curves for these three animal groups are shown in Fig. $8 A$, and their plasma IGF I levels are shown in Fig. $8 \mathrm{~B}$. ang II-infused animals had an expected $25 \%$ loss in body weight at $7 \mathrm{~d}$, compared with sham $(P<0.0001)$, while pair-fed sham-infused animals had a smaller, $18 \%$ loss in body weight at $7 \mathrm{~d}$ compared with sham $(P<0.0001)$. Thus, the loss of body weight in pair-

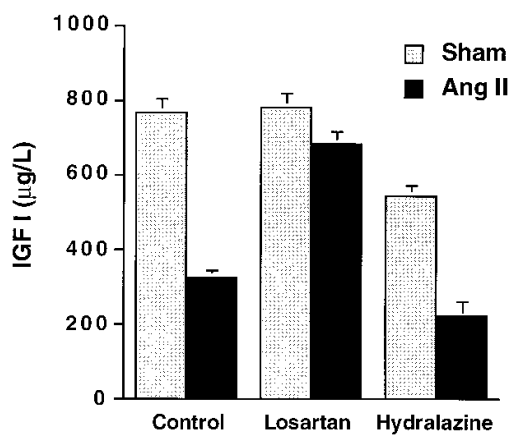

Figure 5. Effect of losartan and hydralazine on ang II regulation of IGF I levels. Total IGF I levels were measured in plasma from shaminfused and ang II-infused rats at $1 \mathrm{wk}$, treated without (Control) or with $25 \mathrm{mg} / \mathrm{kg} / \mathrm{d}$ losartan or $10 \mathrm{mg} / \mathrm{kg} / \mathrm{d}$ hydralazine. Shown are the results of duplicate determinations from four to five animals in each group. fed animals was significantly less than in ang II-infused animals $(P<0.01)$, representing only $74 \%$ of this loss. As expected, IGF I levels in ang II-infused animals were markedly reduced $(72 \%$ reduction, $P<0.01)$. Pair-fed sham-infused animals had a reduction in IGF I levels that was not significantly different than that in ang II-infused animals. Hematocrit levels in ang II-infused animals (39 $\pm 5 \%)$ were not different than in food-restricted animals $(44 \pm 2 \%, P=0.34)$.

Dahl rats. To confirm our conclusion that changes in IGF I are not caused by pressor effects of ang II we used Dahl rats as a model of low-renin hypertension. Salt-sensitive Dahl rats fed a high-salt diet for $2 \mathrm{wk}$ had a significant increase in pressure

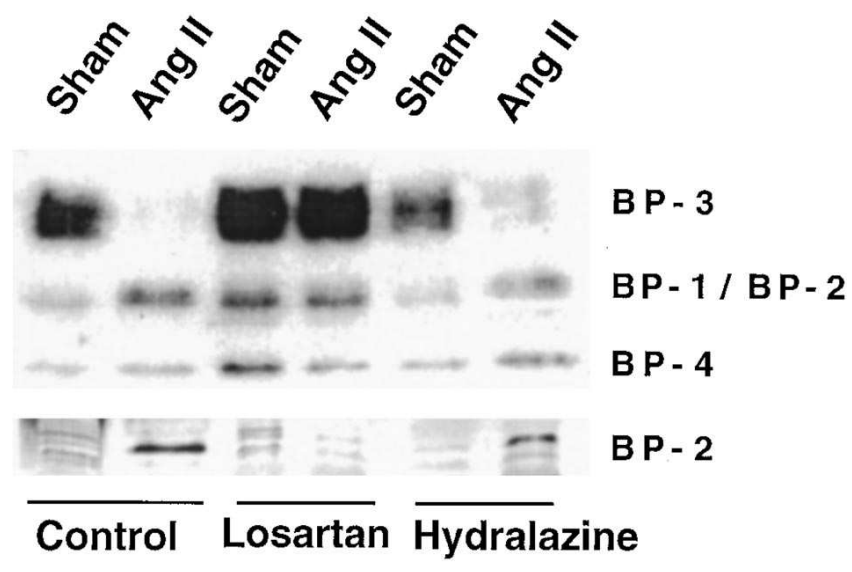

Figure 6. Effect of losartan and hydralazine on ang II regulation of IGFBPs. Plasma from sham-infused and ang II-infused rats at $7 \mathrm{~d}$ treated without (Control) or with $25 \mathrm{mg} / \mathrm{kg} / \mathrm{d}$ losartan or $10 \mathrm{mg} / \mathrm{kg} / \mathrm{d}$ hydralazine was subjected to Western ligand blotting (top three rows) or Western immunoblotting with anti-IGFBP-2 antibody (bottom row). Shown is a representative experiment from one group of animals that was repeated in three additional groups. 

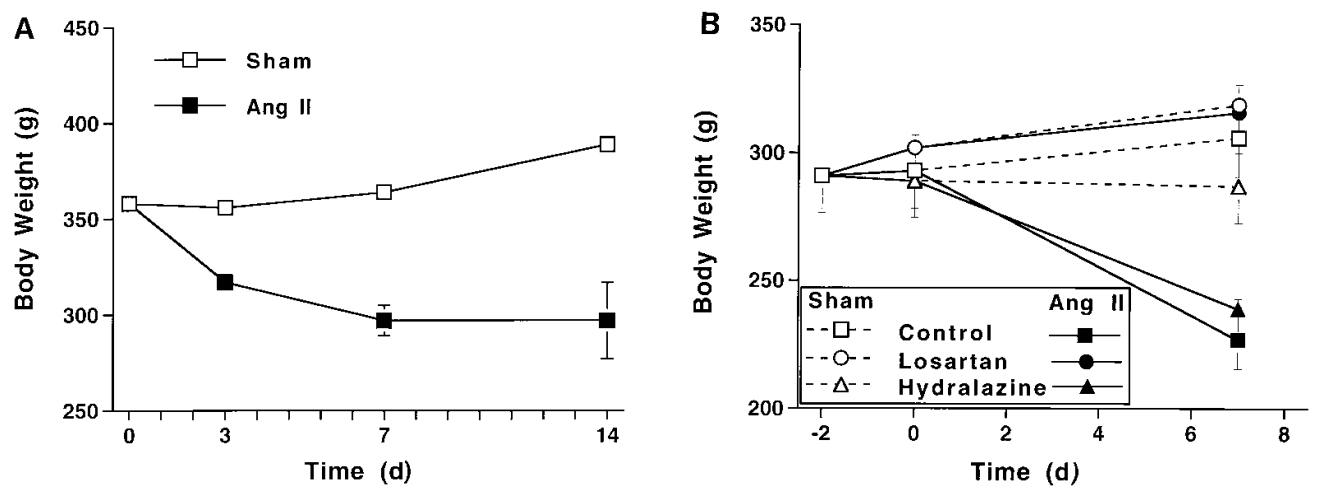

Figure 7. Effect of ang II on body weight. $(A)$ Body weight was determined in sham-infused and ang II-infused rats at indicated times. Shown is the mean $\pm \mathrm{SE}$ of measurements from four to eight animals per condition per time point. (B) Body weight was measured in sham-infused and ang II-infused animals treated without (Control) or with $25 \mathrm{mg} / \mathrm{kg} / \mathrm{d}$ losartan or $10 \mathrm{mg} / \mathrm{kg} / \mathrm{d}$ hydralazine. Shown is the mean \pm SE of measurements from four to six animals per time point per condition.

from $136 \pm 10$ to $188 \pm 5 \mathrm{mmHg}(P<0.01)$. At $2 \mathrm{wk}$, their blood pressure was $33 \%$ higher $(P<0.01)$ than salt-sensitive rats fed a low-salt diet, which had a blood pressure of $142 \pm 5 \mathrm{mmHg}$. As an additional control, we studied salt-resistant Dahl rats fed a high-salt or low-salt diet. Salt-resistant rats on a high-salt diet had a blood pressure at $2 \mathrm{wk}$ of $149 \pm 1 \mathrm{mmHg}$, i.e., $18 \%$ higher than that of salt-resistant rats on a low-salt diet $(126 \pm 6$ $\mathrm{mmHg}, P<0.05)$, but not different than that of salt-sensitive rats on a low-salt diet. At $2 \mathrm{wk}$, these four groups of rats had no significant change either in their plasma IGF I levels (saltsensitive low-salt, $921 \pm 46 \mu \mathrm{g} /$ liter; salt-sensitive high salt, $917 \pm 67 \mu \mathrm{g} /$ liter; salt-resistant low-salt, $841 \pm 51 \mu \mathrm{g} / \mathrm{liter}$; saltresistant high-salt, $928 \pm 15 \mu \mathrm{g} /$ liter) or in levels of IGFBPs (not shown). Furthermore, the weight gain in these four groups of animals was not different over the $2 \mathrm{wk}$ (data not shown).

\section{Discussion}

The main finding of this study was that ang II infusion in the rat caused a significant loss in body weight, which was largely accounted for by a reduction in food intake and was pressor independent. The ang II-infused rats otherwise appeared normal and healthy. Based on pair-feeding experiments, $\sim 26 \%$ of the weight loss induced by ang II infusion at $1 \mathrm{wk}$ was not due to reduced food intake. This effect is therefore likely a metabolic effect. It is unlikely that it represents volume contraction, since ang II has a marked stimulatory effect on thirst (37), and because hematocrit levels measured in the ang II- infused rats were not different than those in pair-fed controls. To determine whether these effects were present at lower doses, we performed an additional experiment using animals infused with $350 \mathrm{ng} / \mathrm{kg} / \mathrm{min}$ ang II $(n=5)$, sham-infused controls fed ad libitum $(n=4)$, and pair-fed sham-infused animals $(n=5)$. As expected, ang II-infused animals had a $21 \%$ loss in body weight at $7 \mathrm{~d}$, compared with sham $(P<0.01)$, while pairfed shams had a smaller $17 \%$ loss in body weight at $7 \mathrm{~d}(P<$ 0.01 compared with sham, $P<0.05$ compared with ang II).

The effect of ang II to produce weight loss was paralleled by marked changes in levels of circulating IGF I and its binding proteins. Specifically, there was at least a twofold reduction in IGF I levels at $7 \mathrm{~d}$, concurrent with a marked reduction in IGFBP-3 levels. In addition, there was an increase in levels of one of the smaller IGFBPs, namely IGFBP-2. These changes are consistent with changes that have been described to occur with chronic nutritional deprivation (38-40). A similar reduction in IGF I levels occurred in pair-fed animals, again suggesting that the primary effect of ang II infusion on IGF I was nutritionally mediated. Animals infused with $350 \mathrm{ng} / \mathrm{kg} / \mathrm{min}$ ang II had a $37 \%$ reduction in IGF I levels at $7 \mathrm{~d}(P<0.01 \mathrm{com}-$ pared with sham), which was also not different than pair-fed sham-infused animals. It is of note that the effect to decrease circulating IGF I levels was confirmed by analysis of hepatic IGF I mRNA levels, which were markedly reduced. This is in contrast to cardiac IGF I mRNA levels, which are upregulated in this model (41), consistent with our prior data showing that ang II stimulates IGF I transcription in extrahepatic tissues, such as vascular smooth muscle $(27,42)$. Cardiac IGF I mRNA
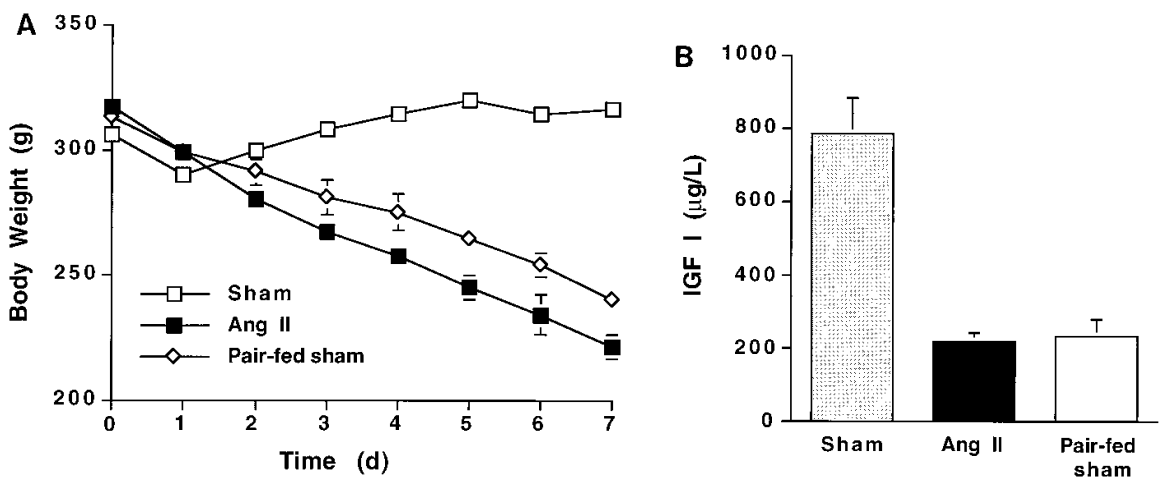

Figure 8. Effect of ang II and of pair-feeding on body weight and IGF I levels. Shaminfused and ang II-infused rats were fed normal rat chow ad libitum. Sham-infused pair-fed rats were fed normal rat chow in quantities identical to those of the ang IIinfused rats. Body weights $(A)$ and IGF I levels at $7 \mathrm{~d}(B)$ were measured as described in Methods. Shown is the mean $\pm \mathrm{SE}$ of results from four rats per time point per condition. 
levels have also been found to be upregulated in other models of pressure and volume overload (43-45).

Experiments with antihypertensive agents indicated that the effect of ang II to produce weight loss and to alter levels of IGF I and its binding proteins was not pressor related. Thus, ang II-induced weight loss was completely reversed by the concomitant administration of the $\mathrm{AT}_{1}$ receptor antagonist, losartan. Hydralazine itself caused a small reduction in body weight at $7 \mathrm{~d}$, compared with sham animals, and also caused a small reduction in basal IGF I levels. Because vasodilators are known to stimulate the RAS (46), one can speculate that this effect of hydralazine alone on weight and on IGF I levels is related to increased ang II levels. More importantly, however, hydralazine completely failed to blunt the ability of ang II to produce weight loss or to depress circulating IGF I levels. In addition, hydralazine did not reverse ang II-induced changes in IGFBPs, as did losartan.

These findings strongly suggest that ang II has an anorexigenic effect on the central nervous system, mediated by the $\mathrm{AT}_{1}$ receptor. It is not possible to conclude from this study whether this effect is direct or, for instance, mediated by stimulation of the sympathetic nervous system. However, Henegar et al. (47), using a protocol similar to ours, have reported that ang II does not increase circulating catecholamine levels until day 4, whereas the weight loss reported in our study is already clearly evident by 1-2 d. Furthermore, infusion of norepinephrine in the Sprague-Dawley rat produces hypertension without weight loss (Bech-Laursen, J., and D. Harrison, personal communication). In addition to its anorexigenic effect, ang II has another (likely metabolic) effect resulting in weight loss. The exact nature of this metabolic effect is currently unknown and will be the subject of investigation in our laboratory. In view of the high density of $\mathrm{AT}_{1}$ receptors on human and rat adipocytes $(48,49)$, one can speculate that ang II may have a lipolytic effect. Our studies with the Dahl rats strongly support the hypothesis that the anorexigenic effect of ang II is not pressor related. Thus, salt loading of the salt-sensitive Dahl rat resulted in a significant increase in blood pressure but no alteration in the normal pattern of weight gain or in IGF I levels. In saltresistant Dahl rats, a high-salt diet did not significantly increase blood pressure and did not alter weight gain or circulating IGF I levels.

Our findings have important implications for understanding the pathophysiology of hyperreninemic states in humans. Indeed, a variety of observations have linked activation of the RAS with increased cardiovascular mortality (22-24). Thus, patients with high-renin hypertension have an increased risk of myocardial infarction. The reasons for this are not understood, but one may speculate that ang II-induced changes in caloric intake and/or in metabolic turnover could occur in these patients. However, our findings are perhaps more relevant to patients with chronic congestive heart failure, in whom ang II levels have been reported to be markedly elevated $(50,51)$. Although we did not measure circulating ang II levels in our model, it is of note that infusion of $200 \mathrm{ng} / \mathrm{kg} / \mathrm{min}$ of ang II in rats results in approximately threefold increases in circulating ang II levels (8), similar to those reported in rats with severe heart failure (52), whereas $600-1,000 \mathrm{ng} / \mathrm{kg} / \mathrm{min}$ results in seven- to eightfold increases in ang II levels (53). In patients with congestive heart failure, seven- to eightfold increases in ang II levels have been reported $(51,54,55)$, which is in the range of the increase that would be expected with the dosages used in our studies. Patients with congestive heart failure commonly have significant anorexia, wasting, and cachexia, the cause of which is currently unknown, although the anorexia has been proposed to be secondary to hepatic and intestinal congestion $(56,57)$. Our findings suggest that the anorexia of heart failure may be secondary to elevated ang II levels. One can speculate that ang II triggers weight loss through its anorexigenic and metabolic effects, leading to a reduction in IGF I. Because IGF I has potent anabolic effects in vivo, these changes could have important detrimental effects. Clearly this hypothesis merits clinical evaluation. In this regard, it is interesting to note that ACE inhibitors profoundly reduce cardiovascular mortality and morbidity in patients with heart failure, clearly more so than other vasodilators (58). Therefore, it is possible that part of the beneficial effects of ACE inhibitors may be due to blunting of the $\mathrm{AT}_{1}$-mediated effects that we are currently reporting.

Our findings are also relevant to the multiple reports relating to physiological effects of ang II infusion in animals (53, 59-68). Although some authors have reported significant weight loss in ang II-infused animals (7, 69-72), there has been no systematic study of this phenomenon. More importantly, because IGF I has multiple physiological effects including stimulation of cellular growth and differentiation, vasoactive effects, metabolic effects, and others (for reviews see references $25,73,74$ ), it becomes apparent that pair-feeding of animals is essential to establish an appropriate control to study the effects of ang II.

In summary, our study demonstrates a marked effect of ang II to produce weight loss in the rat, related to a pressorindependent mechanism. The effect is inhibited by $\mathrm{AT}_{1}$ receptor blockade, predominantly related to a reduction in food intake, and partly related to another, likely metabolic, effect. ang II, through its ability to produce weight loss, markedly alters levels of circulating IGF I and of its binding proteins. Our findings may have potentially great importance in understanding the pathophysiology of conditions in which the RAS is activated.

\section{Acknowledgments}

We are grateful to Kate W. Harris for editorial assistance.

This work is supported by National Institutes of Health grants HL-47035, HL-45317, and DK-45215 and by a grant from the American Heart Association (Georgia Affiliate). Patrick Delafontaine is an Established Investigator of the American Heart Association.

\section{References}

1. Aquitlera, G., and E.T. Marusic. 1971. Role of the renin angiotensin system on the biosynthesis of aldosterone. Endocrinology. 89:1524-1529.

2. Blantz, R.C., K.S. Konnen, and B.J. Tucker. 1976. Angiotensin II effects upon the glomerular microcirculation and ultrafiltration coefficient of the rat. $J$. Clin. Invest. 57:419-434.

3. Hall, J.E. 1986. Control of sodium excretion by angiotensin II: intrarenal mechanisms and blood pressure regulation. Am. J. Physiol. 250:R960-R972.

4. Fitzsimons, J.T. 1980. Angiotensin stimulation of the central nervous system. Rev. Physiol. Biochem. Pharmacol. 87:117-167.

5. Reid, I.A. 1976. The use of saralasin to evaluate the function of the brain renin-angiotensin system. Prog. Biochem. Pharmacol. 12:117-134. 380

6. Saavedra, J. 1991. Brain and pituitary angiotensin. Endocr. Rev. 13:329-

7. Daemen, M.J., D.M. Lombardi, F.T. Bosman, and S.M. Schwartz. 1991 Angiotensin II induces smooth muscle cell proliferation in the normal and injured rat arterial wall. Circ. Res. 68:450-456.

8. Griffin, S.A., W.C. Brown, F. MacPherson, J.C. McGrath, V.G. Wilson, 
N. Korsgaard, M.J. Mulvany, and A.F. Lever. 1991. Angiotensin II causes vascular hypertrophy in part by a non-pressor mechanism. Hypertension (Dallas). 17:626-635.

9. Baker, K.M., and J.F. Aceto. 1990. Angiotensin II stimulation of protein synthesis and cell growth in chick heart cells. Am. J. Physiol. 259:H610-H618.

10. Powell, J.S., J.P. Clozel, R.K. Muller, H. Kuhn, F. Hefti, M. Hosang, and H.R. Baumgartner. 1989. Inhibitors of angiotensin-converting enzyme prevent myointimal proliferation after vascular injury. Science (Wash. DC). 245:186188.

11. Sadoshima, J.-I., and S. Izumo. 1993. Molecular characterization of angiotensin II-induced hypertrophy of cardiac myocytes and hyperplasia of cardiac fibroblasts. Circ. Res. 73:413-423.

12. Schorb, W., G.W. Booz, D.E. Dostal, K.M. Conrad, K.C. Chang, and K.M. Baker. 1993. Angiotensin II is mitogenic in neonatal rat cardiac fibroblasts. Circ. Res. 72:1245-1254.

13. Timmermans, P.B., P.C. Wong, A.T. Chiu, W.F. Herblin, P. Benfield, D.J. Carini, R.J. Lee, R.R. Wexler, J.A. Saye, and R.D. Smith. 1993. Angiotensin II receptors and angiotensin II receptor antagonists. Pharmacol. Rev. 45: 205-251.

14. Unger, T., and P. Gohlke. 1994. Converting enzyme inhibitors in cardiovascular therapy: current status and future potential [published erratum appears in Cardiovasc. Res. 1994. 28:435]. Cardiovasc. Res. 28:146-158.

15. The SOLVD Investigators. 1991. Effect of enalapril on survival in patients with reduced left ventricular ejection fractions and congestive heart failure. N. Engl. J. Med. 325:293-302.

16. The CONSENSUS Trial Study Group. 1987. Effects of enalapril on mortality in severe congestive heart failure. Results of the Cooperative North Scandinavian Enalapril Survival Study (CONSENSUS). N. Engl. J. Med. 316: 1429-1435.

17. The SOLVD Investigators. 1992. Effect of enalapril on mortality and the development of heart failure in asymptomatic patients with reduced left ventricular ejection fractions. N. Engl. J. Med. 327:685-691.

18. Pfeffer, M.A., E. Braunwald, L.A. Moye, L. Basta, E.J. Brown, Jr., T.E. Cuddy, B.R. Davis, E.M. Geltman, S. Goldman, G.C. Flaker, et al. 1992. Effect of captopril on mortality and morbidity in patients with left ventricular dysfunction after myocardial infarction. Results of the survival and ventricular enlargement trial. The SAVE Investigators. N. Engl. J. Med. 327:669-677.

19. Gruppo Italiano per lo Studio della Sopravvivenza nell'infarto Miocardico. 1994. GISSI-3: effects of lisinopril and transdermal glyceryl trinitrate singly and together on 6-week mortality and ventricular function after acute myocardial infarction. Lancet. 343:1115-1122.

20. ISIS-4 Collaborative Group. 1995. ISIS-4: a randomised factorial trial assessing early oral captopril, oral mononitrate, and intravenous magnesium sulphate in 58,050 patients with suspected acute myocardial infarction. ISIS-4 (Fourth International Study of Infarct Survival) Collaborative Group. Lancet. 345:669-685.

21. The Acute Infarction Ramipril Efficacy (AIRE) Study Investigators. 1993. Effect of ramipril on mortality and morbidity of survivors of acute myocardial infarction with clinical evidence of heart failure. Lancet. 342:821-828.

22. Alderman, M.H., S. Madhavan, W.L. Ooi, H. Cohen, J.E. Sealey, and J.H. Laragh. 1991. Association of the renin-sodium profile with the risk of myocardial infarction in patients with hypertension. N. Engl. J. Med. 324:1098-1104.

23. Brunner, H.R., J.H. Laragh, L. Baer, M.A. Newton, F.T. Goodwin, L.R. Krakoff, RH. Bard, and F. R. Buhler. 1972. Essential hypertension: renin and aldosterone, heart attack and stroke. N. Engl. J. Med. 286:441-449.

24. Brunner, H.R., J.E. Sealey, and J.H. Laragh. 1973. Renin as a risk factor in essential hypertension: more evidence. Am. J. Med. 55:295-302.

25. Jones, J.I., and D.R. Clemmons. 1995. Insulin-like growth factors and their binding proteins: biological actions. Endocr. Rev. 16:3-34.

26. Fryburg, D.A., L.A. Jahn, S.A. Hill, D.M. Oliveras, and E.J. Barrett. 1995. Insulin and insulin-like growth factor-I enhance human skeletal muscle protein anabolism during hyperaminoacidemia by different mechanisms. $J$. Clin. Invest. 96:1722-1729.

27. Delafontaine, P., and H. Lou. 1993. Angiotensin II regulates insulin-like growth factor I gene expression in vascular smooth muscle cells. J. Biol. Chem. 268:16866-16870.

28. Delafontaine, P., X.P. Meng, L. Ku, and J. Du. 1995. Regulation of vascular smooth muscle cell insulin-like growth factor I receptors by phosphorothioate oligonucleotides. Effects on cell growth and evidence that sense targeting at the ATG site increases receptor expression. J. Biol. Chem. 270:1438314388

29. Du, J., X.-P. Meng, and P. Delafontaine. 1996. Transcriptional regulation of the insulin-like growth factor I receptor gene by growth factors: evidence for protein kinase C-dependent and -independent pathways. Endocrinology. 137:1378-1384.

30. Ververis, J.J., L. Ku, and P. Delafontaine. 1993. Regulation of insulinlike growth factor I receptors on vascular smooth muscle cells by growth factors and phorbol esters. Circ. Res. 72:1285-1292.

31. Anwar, A., and P. Delafontaine. 1994. Hypertension increases insulinlike growth factor binding protein-4 mRNA levels in rat aorta. Hypertension (Dallas). 24:679-685.

32. Breier, B.H., B.W. Gallaher, and P.D. Gluckman. 1991. Radioimmu- noassay for insulin-like growth factor-I: solutions to some potential problems and pitfalls. J. Endocrinol. 128:347-357.

33. Delafontaine, P., K.E. Bernstein, and R.W. Alexander. 1991. Insulinlike growth factor I gene expression in vascular cells. Hypertension (Dallas). 17: 693-699.

34. Delafontaine, P., H. Lou, and R.W. Alexander. 1991. Regulation of insulin-like growth factor I messenger RNA levels in vascular smooth muscle cells. Hypertension (Dallas). 18:742-747.

35. Fort, P., L. Marty, M. Piechaczyk, S. el Sabrouty, C. Dani, P. Jeanteur, and J.M. Blanchard. 1985. Various rat adult tissues express only one major mRNA species from the glyceraldehyde-3-phosphate-dehydrogenase multigenic family. Nucleic Acids Res. 13:1431-1442.

36. Nelson, D.A., and M.W. Morris. 1991. Basic examination of blood. In Clinical Diagnosis and Management by Laboratory Methods, 18th edition. J.B. Henry, editor. W.B. Saunders, Philadelphia. 553-603.

37. Phillips, P.A., B.J. Rolls, J.G. Ledingham, J.J. Morton, and M.L. Forsling. 1985. Angiotensin II-induced thirst and vasopressin release in man. Clin. Sci. (Colch.). 68:669-674

38. Ketelslegers, J.-M., D. Maiter, M. Maes, L.E. Underwood, and J.-P. Thissen. 1995. Nutritional regulation of insulin-like growth factor-I. Metab. Clin. Exp. 44(Suppl. 4):50-57.

39. Thissen, J.P., J.M. Ketelslegers, and L.E. Underwood. 1994. Nutritional regulation of the insulin-like growth factors. Endocr. Rev. 15:80-101.

40. Underwood, L.E., J.P. Thissen, S. Lemozy, J.M. Ketelslegers, and D.R. Clemmons. 1994. Hormonal and nutritional regulation of IGF-I and its binding proteins. Horm. Res. (Basel). 42:145-151.

41. Brink, M., and P. Delafontaine. 1995. Angiotensin II stimulates insulinlike growth factor I gene expression in rat heart. Circulation. 92(Suppl. 1):I-62a (Abstr.)

42. Fath, K.A., R.W. Alexander, and P. Delafontaine. 1993. Abdominal coarctation increases insulin-like growth factor I mRNA levels in rat aorta. Circ. Res. 72:271-277

43. Donohue, T.J., L.D. Dworkin, M.N. Lango, K. Fliegner, R.P. Lango, J.A. Benstein, W.R. Slater, and V.M. Catanese. 1994. Induction of myocardial insulin-like growth factor-I gene expression in left ventricular hypertrophy. Circulation. 89:799-809.

44. Hanson, M.C., K.A. Fath, R.W. Alexander, and P. Delafontaine. 1993 Induction of cardiac insulin-like growth factor I gene expression in pressure overload hypertrophy. Am. J. Med. Sci. 306:69-74.

45. Wahlander, H., J. Isgaard, E. Jennische, and P. Friberg. 1992. Left ventricular insulin-like growth factor I increases in early renal hypertension. $H y$ pertension (Dallas). 19:25-32.

46. Pettinger, W.A. 1980. Minoxidil and the treatment of severe hypertension. N. Engl. J. Med. 303:922-926.

47. Henegar, J.R., G.L. Brower, A. Kabour, and J.S. Janicki. 1995. Catecholamine response to chronic ANG II infusion and its role in myocyte and coronary vascular damage. Am. J. Physiol. 269:H1564-H1569.

48. Crandall, D.L., H.E. Herzlinger, B.D. Saunders, R.C. Zolotor, L. Feliciano, and P. Cervoni. 1993. Identification and characterization of angiotensin II receptors in rat epididymal adipocyte membranes. Metab. Clin. Exp. 42:511515

49. Crandall, D.L., H.E. Herzlinger, B.D. Saunders, P. Cervoni, L. Kuzmak, and J.G. Kral. 1993. Angiotensin II receptor binding in rat and human fat cell membranes: effects of growth. Pharmacologist. 35:194a. (Abstr.) $88-92$.

. Packer, M. 1992. Pathophysiology of chronic heart failure. Lancet. 340

51. Pedersen, E.B., H. Danielsen, T. Jensen, M. Madsen, S.S. Sorensen, and O.O. Thomsen. 1986. Angiotensin II, aldosterone and arginine vasopressin in plasma in congestive heart failure. Eur. J. Clin. Invest. 16:56-60.

52. Schunkert, H., S.S. Tang, S.E. Litwin, D. Diamant, G. Riegger, V.J. Dzau, and J.R. Ingelfinger. 1993. Regulation of intrarenal and circulating reninangiotensin systems in severe heart failure in the rat. Cardiovasc. Res. 27:731735

53. Tan, L.-B., J.E. Jalil, R. Pick, J.S. Janicki, and K.T. Weber. 1991. Cardiac myocyte necrosis induced by angiotensin II. Circ. Res. 69:1185-1195.

54. Staroukine, M., J. Devriendt, P. Decoodt, and A. Verniory. 1984. Relationships between plasma epinephrine, norepinephrine, dopamine and angiotensin II concentrations, renin activity, hemodynamic state and prognosis in acute heart failure. Acta Cardiol. 39:131-138.

55. Kuroda, T., and H. Shida. 1983. Angiotensin II-induced myocardial damage with a special reference to low cardiac output syndrome. Jpn. Heart J. 24:235-243.

56. Pittman, J.G., and P. Cohen. 1964. The pathogenesis of cardiac cachexia. N. Engl. J. Med. 271:403-409.

57. Carr, J.G., L.W. Stevenson, J.A. Walden, and D. Heber. 1989. Prevalence and hemodynamic correlates of malnutrition in severe congestive heart failure secondary to ischemic or idiopathic dilated cardiomyopathy. Am. J. Cardiol. 63:709-713.

58. Cohn, J.N., G. Johnson, S. Ziesche, F. Cobb, G. Francis, F. Tristani, R. Smith, W.B. Dunkman, H. Loeb, M. Wong, et al. 1991. A comparison of enalapril with hydralazine-isosorbide dinitrate in the treatment of chronic congestive heart failure. N. Engl. J. Med. 325:303-310. 
59. Dostal, D.E., and K.M. Baker. 1992. Angiotensin II stimulation of left ventricular hypertrophy in adult rat heart. Mediation by the AT1 receptor. Am. J. Hypertens. 5:276-280.

60. Geenen, D.L., A. Malhotra, and J. Scheuer. 1993. Angiotensin II increases cardiac protein synthesis in adult rat heart. Am. J. Physiol. 265:H238$\mathrm{H} 243$.

61. Takasaki, I., A.V. Chobanian, R. Sarzani, and P. Brecher. 1990. Effect of hypertension on fibronectin expression in the rat aorta. J. Biol. Chem. 265: 21935-21939.

62. Simon, G., and S. Altman. 1992. Subpressor angiotensin II is a bifunctional growth factor of vascular muscle in rats. J. Hypertens. 10:1165-1171.

63. Simon, G., G. Abraham, and S. Altman. 1994. Stimulation of vascular glycosaminoglycan synthesis by subpressor angiotensin II in rats. Hypertension (Dallas). 23:I148-I151.

64. Crawford, D.C., A.V. Chobanian, and P. Brecher. 1994. Angiotensin II induces fibronectin expression associated with cardiac fibrosis in the rat. Circ. Res. 74:727-739.

65. Abraham, G., and G. Simon. 1994. Autopotentiation of pressor responses by subpressor angiotensin II in rats. Am. J. Hypertens. 7:269-275.

66. Himeno, H., D.C. Crawford, M. Hosoi, A.V. Chobanian, and P. Brecher. 1994. Angiotensin II alters aortic fibronectin independently of hypertension. Hypertension (Dallas). 23:823-826.

67. Kim, S., K. Ohta, A. Hamaguchi, T. Yukimura, K. Miura, and H. Iwao.
1995. Angiotensin II induces cardiac phenotypic modulation and remodeling in vivo in rats. Hypertension (Dallas). 25:1252-1259.

68. Sun, Y., and K.T. Weber. 1993. Angiotensin II and aldosterone receptor binding in rat heart and kidney: response to chronic angiotensin II or aldosterone administration. J. Lab. Clin. Med. 122:404-411.

69. Gronan, R.J., and D.H. York. 1979. Effects of chronic intraventricular administration of angiotensin II on drinking behavior and blood pressure. Pharmacol. Biochem. Behav. 10:121-126.

70. Vari, R.C., S. Zinn, K.M. Verburg, and R.H. Freeman. 1987. Renal nerves and the pathogenesis of angiotensin-induced hypertension. Hypertension (Dallas). 9:345-349.

71. Kabour, A., J.R. Henegar, V.R. Devineni, and J.S. Janicki. 1995. Prevention of angiotensin II induced myocyte necrosis and coronary vascular damage by lisinopril and losartan in the rat. Cardiovasc. Res. 29:543-548.

72. Beck, A., B. Grasmugg, E. Singer, S. Bacher, and G. Raberger. 1985. Angiotensin-induced hypertension in conscious dogs: biochemical parameters and baroreceptor reflex. Cardiovasc. Res. 19:721-726.

73. Werner, H., M. Woloschak, B. Stannard, Z. Shen-Orr, C.T. Roberts, Jr. and D. LeRoith. 1991. The insulin-like growth factor I receptor: molecular biology, heterogeneity, and regulation. In Insulin-Like Growth Factors: Molecula and Cellular Aspects. D. LeRoith, editor. CRC Press, Boca Raton, FL. 17-47.

74. Delafontaine, P. 1995. Insulin-like growth factor I and its binding proteins in the cardiovascular system (review). Cardiovasc. Res. 30:825-834. 